\title{
Evaluation of Therapeutic Treatments to Manage Oak Bacterial Leaf Scorch
}

\author{
John Hartman, Ed Dixon, and Shawn Bernick
}

\begin{abstract}
Bacterial leaf scorch is a very serious tree disease, especially for oaks in Kentucky, U.S. landscapes. From 2003 to 2007 , several potentially therapeutic disease management treatments were tried on diseased pin oaks (Quercus palustris) growing in golf course, street tree, and horse farm environments. Treatments included root flare soil drenches of paclobutrazol, adjuvant-assisted basal trunk applications of anti-microbial compounds, and springtime root flare injections of oxytetracycline. Paclobutrazol drenches caused expected growth regulator effects but did not consistently reduce bacterial leaf scorch of golf course and street trees. Antibiotics applied directly to trunks of infected trees with an adjuvant had no effect on levels of bacterial leaf scorch. Compared to untreated trees, springtime root flare injections of oxytetracycline reduced scorch levels and delayed by about two weeks, the time of appearance of late summer scorch symptoms. Injections done three weeks after full expansion of first leaves provided better results than injections done earlier or later in the spring. Therapeutic treatments do not provide a cure for trees infected with bacterial leaf scorch, but may prolong tree life.

Key Words. Oxytetracycline; Paclobutrazol; Root Flare Injection; Streptomycin; Xylella fastidiosa.
\end{abstract}

Bacterial leaf scorch, caused by Xylella fastidiosa, affects many Kentucky, U.S. landscape trees, including oaks (bur, Quercus macrocarpa; pin, $Q$. palustris; red $Q$. rubra; scarlet, $Q$. coccinea; shingle, $Q$. imbricaria; and white, $Q$. alba); maples (Norway, Acer platanoides; red, A. rubrum; silver, A. saccharinum; and sugar, A. saccharum); planes (American sycamore, Platanus occidentalis, and London plane, $P . \times$ acerifolia); sweetgum, Liquidambar styraciflua; hackberry, Celtis occidentalis; elm, Ulmus americana; and mulberry, Morus rubra (Hartman et al. 1991; Hartman et al. 1992; Hartman et al. 1995; Hartman et al. 1996; Beale et al. 2002). Leaves of infected trees typically show marginal necrosis (scorch) late in the summer followed by premature defoliation. Infected trees re-foliate normally in spring and the process of late summer scorch and premature defoliation is repeated. The disease begins on one or a few branches and over several years gradually spreads throughout the tree. After many years, dead twigs, then dead branches and limbs begin to appear in the tree and the condition continues to worsen until the tree is in serious decline and needs removal. Bacterial leaf scorch is a very problematic plant disease in Kentucky.

The disease-causing bacterium, $X$. fastidiosa, has a wide host range, and symptoms vary with host plant (Hopkins 1989). X. fastidiosa is vectored by leafhopper insects (Bentz and Sherald 2001; Pooler et al. 1997). This pathogen exists as several subspecies including $X$. fastidiosa subspecies multiplex, the probable cause of bacterial leaf scorch of most landscape trees (Schaad et al. 2004). More than 40 tree species growing throughout North America have been identified as hosts of X. fastidiosa, which makes bacterial leaf scorch a widespread and serious threat to urban forests (Anonymous 1993; Gould et al. 2004; Gould and Lashomb 2005; Sherald 2007).
Paclobutrazol (PBZ) is a plant growth regulator chemical which inhibits synthesis of the plant hormone gibberellin. The chemical is said to suppress shoot growth and stimulate root development which could reduce bacterial leaf scorch symptoms. At relatively high rates in the laboratory, $\mathrm{PBZ}$ suppresses growth of $X$. fastidiosa (DeStefano et al. 2007). Preliminary evidence suggests that application of PBZ may improve tree health and reduce the effects of plant disease. The chemical suspension is applied as a soil drench around the base of the tree and is taken up into the tree systemically. PBZ effects may not appear until the year after the treatments, but its beneficial effects are thought to last for three years.

Organosilicate surfactants (surfactant) serve to promote the penetration of applied chemicals through the bark of treated trees to the vascular system. Phosphite-containing materials (phosphite) such as Agrifos $^{\circledR}$ (Agrichem Manufacturing Industries Pty. Ltd., Loganholme, Queensland, Australia) have been shown to have activity against some bacterial diseases such as fire blight (Brannen and Garner 2008). Surfactantcontaining mixtures are sprayed on the bark surface, wetting the tree bark as far as the application will allow, normally on the lower $2 \mathrm{~m}$ of the trunk. Surfactant plus phosphite is useful in control of sudden oak death, caused by Phytophthora ramorum (Garbelotto et al. 2007; Garbelotto and Schmidt 2009).

Antibiotics such as streptomycin sulfate and oxytetracycline are active against gram negative bacteria such as $X$. fastidiosa. These antibiotics are already used for management of bacterial diseases of many agricultural crops. Oxytetracycline has been shown to delay bacterial leaf scorch symptoms in elm (Kostka et al. 1985).

The objectives of this research on therapeutic treatments of oaks already infected with bacterial leaf scorch were to test the following hypotheses: 
* Root flare soil drench treatments of PBZ would reduce bacterial leaf scorch disease symptoms.

* Using an adjuvant, trunk-applied anti-bacterial chemicals or growth regulators would reduce bacterial leaf scorch disease symptoms.

* Root flare injections of oxytetracycline antibiotic would reduce bacterial leaf scorch disease symptoms.

* An optimal time for springtime oxytetracycline injections to have maximum effect on bacterial leaf scorch disease could be determined.

\section{MATERIALS AND METHODS}

All experiments were conducted on mature Quercus palustris (pin oak) in and around Lexington, Kentucky $\left(38^{\circ} \mathrm{N}, 84.5^{\circ} \mathrm{W}\right)$, at several different locations within $5 \mathrm{~km}$ of Lexington.

Disease severity evaluations were made on each individual tree by estimating the amount of foliage with scorch symptoms as a percent of total foliage. Each tree was evaluated by a single observer taking data from all sides of the tree. In most of the experiments, disease severity ratings were also done the year before at roughly the same date so that comparisons could be made from one year to the next. To visualize these comparisons, data are presented graphically so that disease severity can be seen as a percent of the previous year's disease severity. For statistical comparisons, analysis of absolute values of disease severity and areas under the disease progress curve (AUDPC) were also made. Results were statistically analyzed using the Waller-Duncan LSD Mean Separation Test.

\section{PBZ Drench Treatment}

\section{Experiment 1}

The experiment was established on pin oaks with varying levels of bacterial leaf scorch growing on the Idle Hour Country Club golf course in Lexington. Ten golf course oaks, average diameter at $1.4 \mathrm{~m}$ above ground $(\mathrm{DBH}=94 \mathrm{~cm})$, were treated July 2003. At the time of treatment, a shallow trench encircling the base of the tree was dug around the buttress roots and trunk. PBZ was applied at labeled rates to the trench at the base of the oaks. Each tree was paired with a tree of similar age, placement, and condition which was treated only with water. The experiment was designed as a randomized complete block with 10 replications. Oaks were evaluated in October 2003, October 2004, October 2005, and October 2006. Symptoms of leaf scorch on each tree were observed and a percentage incidence was assigned for each. Photographs were also taken so that tree health progress could be noted over the years.

\section{Experiment 2}

The experiment was established on pin oaks with varying levels of bacterial leaf scorch growing as street-side trees in several Lexington neighborhoods. During August 2003-October 2003, the oaks (average $\mathrm{DBH}=78$ $\mathrm{cm}$ ), were treated with PBZ or used as water-treated controls as previously described. Annual disease evaluation records were completed 2003-2005 as previously described.

\section{Surfactant-Assisted Treatment}

Eighty street-side pin oak trees, average $\mathrm{DBH}=75 \mathrm{~cm}$, growing in a Lexington neighborhood with a history of bacterial leaf scorch disease were selected for this experiment. Trunk treatments were applied July 13-14, 2005, and where two treatments were required, repeated August 24, 2005. Treatments were applied to all surfaces of individual tree trunks from approximately $5 \mathrm{~cm}$ above the ground to a height of approximately $2 \mathrm{~m}$ using a hand-pumped backpack sprayer $\left(\mathrm{Solo}^{\circledR}\right.$, Newport News, VA, U.S.) delivering spray at a pressure of $1.8 \mathrm{~kg} / \mathrm{cm}^{2}$. Each tree trunk received $1.5 \mathrm{~L}$ of suspension. The PBZ basal drench treatment was applied as previously described, on July 19, 2005. The eight treatments (Table 1) were replicated 10 times and the experiment was established in a randomized complete block design. Prior to treatment applications, while foliage was still green, trees were evaluated for dieback (an indicator of chronic leaf scorch) in early July 2005, so that trees representing varying stages of disease could be distributed equally among the treatments. On September 27, 2005, and again October 19, 2006, trees were evaluated for percent scorch symptoms.

\section{Antibiotic Root Flare Injections}

For all injection treatment experiments, pin oaks for use in experimental plots were evaluated for bacterial leaf scorch when symptoms were prominent the year before treatment applications. From these data, trees with varying levels of leaf scorch $(0 \%-100 \%)$ were equally assigned to each treatment group so that no treatment was compromised by use on predominantly heavily diseased trees and compared with another treatment used on predominantly healthy trees. Prior to 2006 treatments (Experiment 1), oaks were evaluated for scorch on October 18, 2005; and prior to 2007 treatments (Experiments 2 and 3); oaks were evaluated on October 18 and 19, 2006, respectively.

\section{Experiment 1}

To test the efficacy of therapeutic treatments in 2006, plots were established at Stone Street Farm in Lexington, a horse farm with a history of bacterial leaf scorch disease. Eighty pin oaks (average $\mathrm{DBH}=55 \mathrm{~cm}$ ), lining a long driveway and growing along the boundaries of the farm, were selected for this experiment. Based on data from the previous year (2005), average leaf scorch was $30 \%-36 \%$ for each treatment group. Therapeutic treatments compared injected antibiotics and injection methods to soil drench and trunk applications for reducing bacterial scorch symptoms. The eight treatments (Table 2) were applied during June 2006 , and replicated 10 times in a randomized complete block design. In 2006, trees were evaluated for percent leaf scorch symptoms on August 15; September 6 and 21; and October 3 and 18.

Oxytetracycline hydrochloride (Bacastat ${ }^{\mathrm{TM}}$ OSC, Rainbow Treecare Scientific Advancements, Minneapolis, MN, U.S.) or oxytetracycline phosphate (Bacastat OSP, Rainbow Treecare Scientific Advancements, Minneapolis, MN, U.S.) antibiotics were injected using one of two methods: 1) a macro-infusion technique, or 2) a micro-injection technique. Macro-infusions were made following the protocol developed by Rainbow Treecare Scientific Advancements. Infusion sites were made 13-20 $\mathrm{cm}$ below the tops of root flares through $0.6 \mathrm{~cm}$ holes drilled into the basal flare roots which were exposed by removing soil around the base of the tree with an air excavator (Supersonic Air 
Knife, Inc, Allison Park, PA, U.S.). Drilled holes, spaced about $15 \mathrm{~cm}$ apart on the root flares, were fitted with a series of plastic "tees" and harnessed to the output of a hand pump sprayer to deliver the required suspension evenly all around the tree.

Micro-injections were done with a microinjection device (M3 Microinjector, Rainbow Treecare Scientific Advancements, Minnetonka, MN, U.S.), which was capable of generating pressure to facilitate uptake of the solution being applied. Applications were made through $0.4 \mathrm{~cm}$ diameter holes drilled into major root flares at the base of the tree and spaced 15-20 cm apart around the tree. Basal trunk soil drench applications and trunk spray applications were applied as previously described.

Table 1. Pin oak (Quercus palustris) trunk and basal drench treatments (Summer 2005).

\begin{tabular}{|c|c|c|}
\hline Treatments & Product Rate & Surfactant Rate \\
\hline (1) Untreated Control & - & - \\
\hline (2) surfacant $^{z}+$ oxytetracycline $^{y}$ & $5.9 \mathrm{~g} / \mathrm{L}$ & $2.5 \%$ by volume \\
\hline $\begin{array}{l}\text { (3) } \text { surfacant }^{z}+\text { oxytetracycline }^{y} \\
\text { (applied twice) }\end{array}$ & $5.9 \mathrm{~g} / \mathrm{L}$ & $2.5 \%$ by volume \\
\hline (4) surfacant $^{2}+$ phosphite $^{x}$ & $25 \%$ solution by volume & $2.5 \%$ by volume \\
\hline (5) surfacant $^{2}+\mathrm{PBZ}^{\mathrm{w}}$ & $33 \%$ solution by volume & $2.5 \%$ by volume \\
\hline $\begin{array}{l}\text { (6) } \text { surfacant }^{2}+\text { streptomycin } \\
\text { sulfate }^{v}\end{array}$ & $5.9 \mathrm{~g} / \mathrm{L}$ & $2.5 \%$ by volume \\
\hline $\begin{array}{l}\text { (7) } \text { surfacant }^{2}+\text { streptomycin } \\
\text { sulfate }^{v} \text { (applied twice) }\end{array}$ & $5.9 \mathrm{~g} / \mathrm{L}$ & $2.5 \%$ by volume \\
\hline (8) $\mathrm{PBZ}^{\mathrm{w}}$ (basal drench) & $1.6 \mathrm{~g}$ a.i././ $\mathrm{cm} \mathrm{DBH}$ & - \\
\hline
\end{tabular}

${ }^{\mathrm{z}}$ Pentrabark ${ }^{\mathrm{TM}}$, Agrichem, Medina, OH, U.S.

${ }^{y}$ Myco-Shield ${ }^{\circledR}$, Nufarm, Burr Ridge, IL, U.S

xAgrifos, Agrichem Manufacturing Industries Pty. Ltd., Loganhome, Queensland, Australia

${ }^{w}$ Cambistat, Rainbow Treecare Scientific Advancements, Minneapolis, MN, U.S.

${ }^{\mathrm{N} A g r i m y c i n} 22.7 \%$, Nufarm, Burr Ridge, IL, U.S.

\section{Experiment 2}

To determine the best application timing in spring, additional plots were established at Stone Street Farm in 2007. Fifty pin oak trees with an average DBH of $55 \mathrm{~cm}$ were selected for this experiment. Oxytetracycline hydrochloride was injected during spring 2007, into trees using the micro-injection technique, but with $0.6 \mathrm{~cm}$ diameter drill holes. The first group of oaks was injected on May 8-9, a second group approximately three weeks later on May 29-30 or June 1, and a third group on June 18 or 20 . The first group received injections when first new leaves were fully expanded. Compared to normal seasonal leaf phenology, the timing was delayed a week or two because of an early April 2007 freeze. Chemical uptake time using this system ranged from 10 to 30 minutes. Calcium complex oxytetracycline was applied similarly but with an approximately two-day uptake time due to the more viscous formulation used. Treatments are listed in Table 3. Based on data from the previous year (2006), average leaf scorch was $40 \%-50 \%$ for each treatment group. The five treatments were replicated 10 times and the experiment was established in a randomized complete block design. Beginning with first symptom appearance, trees were evaluated for percent scorch symptoms at roughly two-week intervals, on August 7 and 20; September 4 and 18; and October 2, 16, and 30, 2007.

\section{Experiment 3}

To test the efficacy of root flare injection of antibiotic on pin oaks growing as street-side trees, plots were established in a Lexington neighborhood with a history of bacterial leaf scorch dis-

Table 2. Root flare injection, basal drench, and trunk treatments (Summer 2006).

\begin{tabular}{|c|c|c|c|}
\hline Treatment & Date & Rate & Application method \\
\hline (1) Oxytetracycline hydrochloride ${ }^{z}$ & June 21 or June 22 & $\begin{array}{l}0.6 \text { grams in } 150 \mathrm{ml} \text { water } \\
\text { per } 2.5 \mathrm{~cm} \text { tree diameter }\end{array}$ & pressurized macroinjection \\
\hline (2) Oxytetracycline hydrochloride ${ }^{z}$ & June 26 or June 27 & $\begin{array}{l}0.6 \text { grams in } 9 \mathrm{ml} \text { water } \\
\text { per } 2.5 \mathrm{~cm} \text { tree diameter }\end{array}$ & pressurized microinjection \\
\hline (3) Oxytetracycline hydrochloride ${ }^{z}$ & June 21 or June 22 & 0.6 grams in $150 \mathrm{ml}$ water & $\begin{array}{l}\text { pressurized macroinjection } \\
+ \text { basal drench }\end{array}$ \\
\hline$+\mathrm{PBZ}^{\mathrm{y}}$ & + June 1 or June 2 & $\begin{array}{l}\text { per } 2.5 \mathrm{~cm} \text { tree diameter } \\
+4 \text { grams a.i. per } 2.5 \mathrm{~cm} \text { tree } \\
\text { diameter (rate F from } \\
\text { Cambistat application } \\
\text { rate card) }\end{array}$ & \\
\hline $\begin{array}{l}\text { (4) Oxytetracycline hydrochloride } \\
+ \text { PBZ }^{y}\end{array}$ & $\begin{array}{l}\text { June } 26 \text { or June } 27 \\
+ \text { June } 1 \text { or June } 2\end{array}$ & $\begin{array}{l}0.6 \text { grams in } 9 \mathrm{ml} \text { water } \\
\text { per } 2.5 \mathrm{~cm} \text { tree diameter } \\
+4 \text { grams a.i. per } 2.5 \mathrm{~cm} \\
\text { tree diameter (rate } \mathrm{F} \text { from } \\
\text { Cambistat application } \\
\text { rate card) }\end{array}$ & $\begin{array}{l}\text { pressurized microinjection } \\
+ \text { basal drench }\end{array}$ \\
\hline (5) $\mathrm{PBZ}^{\mathrm{y}}$ & June 1 or 2 & $4 \mathrm{~g}$ a.i. per $2.5 \mathrm{~cm} \mathrm{DBH}$ & basal drench \\
\hline (6) Surfactant + phosphite ${ }^{x}$ & June 5 & $\begin{array}{l}2.5 \% \text { solution }+25 \% \\
\text { solution in } 1.5 \text { liters }\end{array}$ & trunk spray from the ground to $2 \mathrm{~m}$ \\
\hline (7) Oxytetracycline phosphate ${ }^{w}$ & June 29 & $\begin{array}{l}0.6 \text { grams in } 9 \mathrm{ml} \text { water/ } \\
2.5 \mathrm{~cm} \text { tree diameter }\end{array}$ & pressurized microinjection \\
\hline (8) Untreated control & - & - & - \\
\hline
\end{tabular}

${ }^{2}$ Bacastat OSC, Rainbow Treecare Scientific Advancements, Minneapolis, MN, U.S.

${ }^{y}$ Cambistat, Rainbow Treecare Scientific Advancements, Minneapolis, MN, U.S.

${ }^{x}$ Agrifos, Agrichem Manufacturing Industries Pty. Ltd., Loganhome, Queensland, Australia

wBacastat OSP, Rainbow Treecare Scientific Advancements, Minneapolis, MN, U.S. 
ease. Twenty-four pin oaks with an average DBH of $75 \mathrm{~cm}$ were selected for this experiment. Using the micro-injection technique previously described, oxytetracycline hydrochloride was applied to twelve of the trees the week of June 8-15, 2007, at the rate of 0.14 grams a.i. in $7.5 \mathrm{ml}$ water $/ 2.5 \mathrm{~cm}$ tree diameter (label rate). Based on data from the previous year (2006), average leaf scorch was $60 \%$ for each treatment group. The two treatments (oxytetracycline hydrochloride-treated versus untreated) were replicated 12 times and the experiment was established in a randomized complete block design. Beginning with first symptom appearance, trees were evaluated for percent scorch symptoms at about two-week intervals on August 9 and 23; September 6 and 20; and October 4, 20, and 31, 2007.

\section{RESULTS}

\section{PBZ Drench Treatment}

\section{Experiment 1}

In the golf course environment, from 2003 to 2006, average bacterial leaf scorch symptoms of PBZ-treated trees decreased gradually from $18 \%$ to $13.7 \%$, while average scorch of water-treated trees increased from $18.1 \%$ to $28 \%$ over the same three years. These results were not statistically significant $(P=0.05)$. On the golf course, annual increase in trunk diameter of water treatedtrees was $0.4 \mathrm{~cm}$, compared to $0.13 \mathrm{~cm}$ for PBZ-treated trees.

\section{Experiment 2}

Along the city streets from 2003 to 2006, average bacterial leaf scorch symptoms of PBZ-treated trees increased gradually from $41 \%$ to $79.5 \%$, while average scorch of water-treated trees increased from $42.1 \%$ to $72.5 \%$ over the same three years. Street-side pin oaks in the experiment were generally more severely diseased than those on the golf course and PBZ treatments made little impact on scorch levels. These results were not statistically significant $(P=0.05)$.

\section{Surfactant-Assisted Treatment}

Bacterial leaf scorch symptoms increased for all treatments from 2005 to 2006. If there had been no treatments, it would be expected that leaf scorch symptoms would increase gradually from one year to the next in any case. Average bacterial leaf scorch ranged from $13 \%$ to $40 \%$ in 2005 , and from $37 \%$ to $67 \%$ in 2006 , depending on the treatment. None of the treatments reduced or moderated scorch levels in 2005 and in 2006.
Where surfactant was used, grayish blue-green colored crustose lichens growing on the bark surface developed a light brown color and any plant foliage exposed to the chemical turned brown.

\section{Antibiotic Root Flare Injections Experiment 1}

Results are presented in Figure 1. The graph represents scorch levels as a percent of the previous year's leaf scorch, but statistics are based on differences in absolute scorch values. Treatments using antibiotics generally delayed the onset of symptoms by approximately two to three weeks. By the end of the 2006 growing season, these same treatments resulted in less disease than was present in the trees the year before, while untreated trees were more diseased than the previous year.

\section{Experiment 2}

Results are presented in Figure 2. The graph represents scorch levels as a percent of the previous year's leaf scorch, but statistics are based on differences in season-long area under the disease progress curve (AUDPC) values. For all treatments, bacterial leaf scorch symptoms gradually increased from August through October. Antibiotic treatments generally delayed the onset of symptoms by approximately two to three weeks. It appears that the late May oxytetracycline hydrochloride treatment (three weeks after first leaves were fully expanded) provided slightly better results than the early May or midJune treatments. Calcium complex oxytetracycline treatments were not as effective as oxytetracycline hydrochloride treatments made on similar application dates. By mid-October, the antibiotic-treated trees showed less scorch than the same trees showed at about the same time in October 2006. At the same time, untreated trees were more diseased than the previous year.

\section{Experiment 3}

Results are presented in Figure 3. The graph represents scorch levels as a percent of the previous year's leaf scorch. Bacterial leaf scorch symptoms gradually increased from August through October for both treatments. Oxytetracycline hydrochloride treatment generally delayed the onset of symptoms by approximately one to two weeks but these differences were not statistically significant. By mid-October, untreated trees were more diseased than the previous year, while the antibiotic-treated trees showed less scorch than the same trees showed at about the same time in October 2006.

Table 3. Root flare injection treatments (Spring and Summer 2007).

\begin{tabular}{|c|c|c|c|}
\hline Treatment & Date & Rate & Application method \\
\hline $\begin{array}{l}\text { Oxytetracycline } \\
\text { hydrochloride }^{z}\end{array}$ & May 8 or May 9 & $\begin{array}{l}0.14 \text { grams a.i. in } 7.5 \mathrm{ml} \text { water/ } \\
2.5 \mathrm{~cm} \text { tree diameter (label rate) }\end{array}$ & pressurized microinjection \\
\hline $\begin{array}{l}\text { Oxytetracycline } \\
\text { hydrochloride }^{z}\end{array}$ & May 29 or May 30 & $\begin{array}{l}0.14 \text { grams a.i. in } 7.5 \mathrm{ml} \text { water/ } \\
2.5 \mathrm{~cm} \text { tree diameter (label rate) }\end{array}$ & pressurized microinjection \\
\hline $\begin{array}{l}\text { Oxytetracycline } \\
\text { hydrochloride }^{z}\end{array}$ & June 18 or June 20 & $\begin{array}{l}0.14 \text { grams a.i. in } 7.5 \mathrm{ml} \text { water/ } \\
2.5 \mathrm{~cm} \text { tree diameter (label rate) }\end{array}$ & pressurized microinjection \\
\hline $\begin{array}{l}\text { Calcium complex } \\
\text { oxytetracycline }^{y}\end{array}$ & June 1 & $\begin{array}{l}0.13 \text { grams a.i. in } 3 \mathrm{ml} \text { suspension/ } \\
2.5 \mathrm{~cm} \text { tree diameter (label rate) }\end{array}$ & pressurized microinjection \\
\hline Untreated control & - & - & - \\
\hline
\end{tabular}

${ }^{2}$ Bacastat OSC, Rainbow Treecare Scientific Advancements, Minneapolis, MN, U.S.

${ }^{\mathrm{y}}$ Mycoject, Mauget Inc., Arcadia, CA, U.S. 


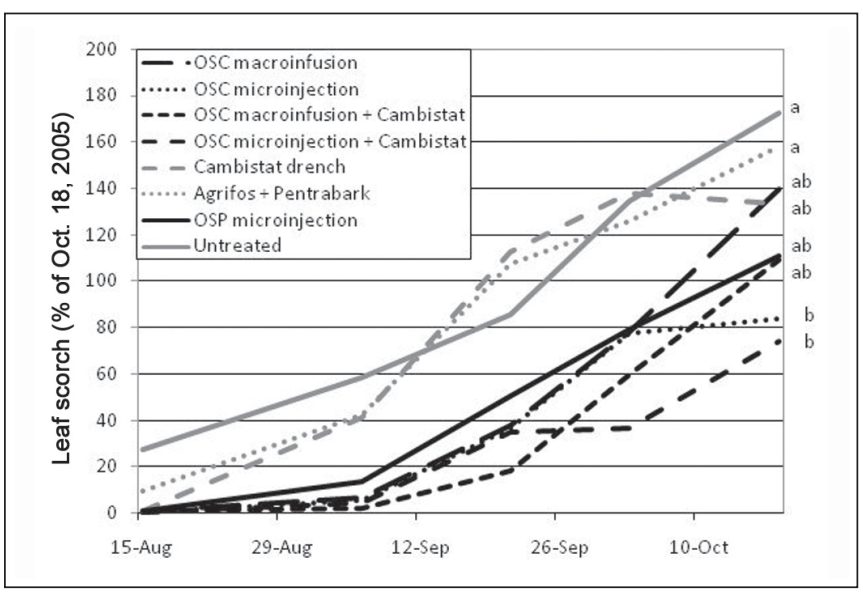

Figure 1. Effect of therapeutic treatments on 2006 bacterial leaf scorch disease progress in horse farm oaks expressed as percent of October 18, 2005, disease levels. Actual October 18, 2005, scorch levels for each treatment group ranged from $30 \%$ to $36 \%$ (all trees previously untreated). When a treatment line equals $100 \%$, the scorch level of the previous year (October 18, 2005) has been reached. Actual scorch levels on October 18, 2006, ranged from $24 \%$ (Oxytetracycline hydrochloride microinjection plus PBZ) to $57 \%$ (untreated control). Graph lines followed by the same lowercase letters are not significantly different ANOVA LSD mean separation $(P=0.05)$.

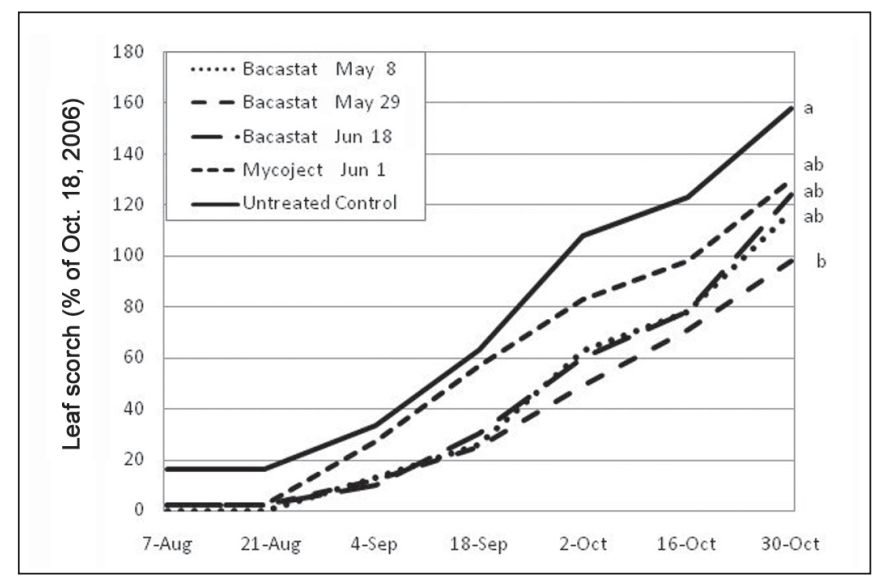

Figure 2. Effect of timing of oxytetracycline hydrochloride treatments on 2007 bacterial leaf scorch disease progress in horse farm oaks expressed as percent of October 18, 2006, disease levels. Actual October 18, 2006, scorch levels for each treatment group ranged from $\mathbf{5 0} \%$ to $\mathbf{5 4} \%$ (all trees previously untreated). When a treatment line equals $100 \%$, the scorch level of the previous year (October 18, 2006) has been reached. Actual scorch levels on October 16 and October 30,2007 , ranged from $37 \%$ and $51 \%$, respectively (Oxytetracycline hydrochloride May 29 microinjection), to $64 \%$ and $82 \%$ (untreated control). Graph lines followed by the same lowercase letters are not significantly different ANOVA LSD mean separation $(P=0.0024)$.

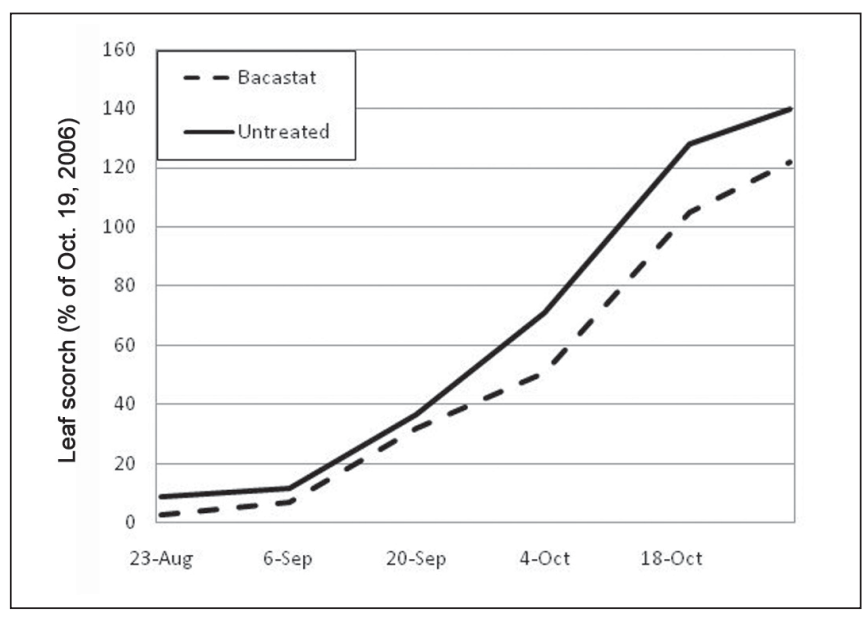

Figure 3. Effect of oxytetracycline hydrochloride treatment on 2007 bacterial leaf scorch disease progress in street-side oaks expressed as percent of October 19, 2006, disease levels. Actual October 19, 2006, scorch levels for each treatment group ranged from $62 \%$ to $63 \%$ (all trees untreated). When a treatment line equals $100 \%$, the scorch level of the previous year (October $19,2006)$, has been reached. Actual scorch levels on October 20 , 2007 , ranged from $65 \%$ (oxytetracycline hydrochloride microinjection) to $80 \%$ (untreated control). Results were not statistically different, ANOVA LSD mean separation $(P=0.05)$.

\section{DISCUSSION}

\section{PBZ Drench Treatment}

On the golf course, within each group of 10 trees, scorch levels in some individual trees decreased over the three years, while others showed more scorch, but there were more increases in the water treated oaks. Thus, although PBZ application appears to benefit some individual bacterial leaf scorch-infected pin oaks, other individuals were not similarly affected; as a result, statistically significant differences could not be calculated. Nevertheless, a trend may be occurring. PBZ reduced oak trunk diameter growth and appeared to reduce terminal shoot growth. Also, on the golf course, six of 10 PBZ-treated trees appeared to have darker green foliage by the end of the experiment while only one of 10 water-treated trees showed this trait. In the street-tree infected oaks, scorch symptoms were much more advanced to begin with and treatment effects were not apparent. The bacteriostatic effects of PBZ on X. fastidiosa noted in the laboratory (DeStefano et al. 2007), were not apparent in the field. Golf course pin oaks were favored with better growing conditions than street-side trees in this experiment. Growing along the edge of fairways, these trees had much more rooting space and were watered regularly along with the turfgrass during periods of drought.

\section{Surfactant-Assisted Treatment}

Application of antibiotics or other scorch-disease-suppressing agents directly through the bark using the surfactant did not have a beneficial effect for bacterial leaf scorch disease management in the present study. Although phosphite suppressed fire blight when applied to foliage of apple trees, application of phosphite to the trunk with surfactant did not suppress fire blight (Brannen and Garner 2008). Surfactant is used success- 
fully to assist in the movement of therapeutic phosphite chemicals into trees susceptible to sudden oak death disease (Garbelotto et al. 2007; Garbelotto and Schmidt 2009). It is possible that phosphite chemistry does not affect $X$. fastidiosa. For the antibiotics streptomycin and oxytetracycline, there is no assurance that surfactant actually moves these materials into the tree.

\section{Antibiotic Root Flare Injections}

None of the antibiotic treatments "cured" infected trees or prevented scorch symptoms from appearing by the end of the growing season. This is consistent with previous reports of oxytetracycline effects on bacterial leaf scorch of elm (Kostka et al. 1985). However, it is clear that springtime treatment with antibiotic reduces bacterial leaf scorch and delays summertime scorch symptom expression. Based on these results, root flare injection done about three weeks after first leaves are fully expanded appears to be an optimal time. For the 2007 trials (Experiment 2), it is not known whether the spring freeze or summer drought affected the treatments or disease expression. It appeared that healthy leaves remained greener a week or two longer into the fall than normal so final disease evaluations were continued somewhat later in 2007 than in 2006. In the street tree trial (Experiment 3), oxytetracycline hydrochloride results might have been enhanced if the injections had been done in late May, rather than mid June.

\section{IMPLICATIONS FOR ARBORICULTURE}

Management of bacterial leaf scorch in oaks already infected with bacterial leaf scorch is very difficult. Arborists are in need of a remedy for bacterial leaf scorch disease. Although treatments used in this experiment did not cure trees of bacterial leaf scorch, treatments that can delay symptoms by even a few weeks might prolong the useful life of infected trees. These results suggest that by using methods readily available to the industry, symptoms can be delayed during the growing season. In the experience of the study authors, making repeat treatments on the same tree continues to delay symptoms each year (data not shown), without actually providing a cure. Whether delaying symptoms annually actually extends the useful life of infected trees is not known and would require additional long-term experiments.

Arborists should consider using various management practices aimed at extending the longevity of mature specimen trees infected with bacterial leaf scorch. These practices may include treatment with antibiotics, reduction of water stress through proper mulching and timely irrigation, and management of secondary insects and diseases. For future disease management, it is hoped that a biological control treatment using a benign strain of $X$. fastidiosa can be developed for bacterial leaf scorch of landscape trees. This concept is already being studied for management of Pierce's Disease of grapes (Hopkins 2005).

Replication in tree disease management field trials is a necessary step for product and method testing because what may be effective on one or two individual trees may or may not work consistently on other trees nearby. Arborists should also appreciate the difficulties of conducting replicated experiments on naturallyinfected mature trees in the field because not all trees are uniformly infected at the start of the experiment. For example, in all experimental groups in this study, October tree scorch symptoms were highly variable from tree to tree, ranging from no scorch to $100 \%$ of leaves showing symptoms. Without adequate replication, this variability can lead to erratic results and difficult statistical analysis. This work was done in populations of pin oaks; bacterial leaf scorch of other tree species might not respond in the same way.

Acknowledgments. Gale Moore, Stone Street Farm; Eddie Hodges, Idle Hour Country Club; Larry Hanks, Pampered Properties; Bernadette Amsden, Department of Plant Pathology; Stacy Borden, Dave Leonard Consulting Arborist; and Claudia Cotton and Tobias Fullwood, student interns.

\section{LITERATURE CITED}

Anonymous. 1993. Bacterial leaf scorch of landscape trees. Center for Urban Ecology Information Bulletin. National Park Service. Washington, D.C. 4 pp.

Beale, J., P. Bachi, and J. Hartman. 2002. Landscape plant disease observations from the plant disease diagnostic laboratory - 2002. pp. 22-23. In: University of Kentucky Agricultural Experiment Station 2002 Nursery and Landscape Program Research Report 468.

Bentz, J., and J. Sherald. 2001. Transmission of the xylem-limited bacterium Xylella fastidiosa to shade trees by insect vectors. pp. 203-208. In: C. Ash (Ed.). Shade Tree Wilt Diseases. American Phytopathological Society. St. Paul, MN.

Brannen, P.M., and J.C. Garner. 2008. Evaluation of products for control of fire blight in Georgia, 2007. Plant Disease Management Reports 2:PF019. <http://www.plantmanagementnetwork.org/pub/trial/ PDMR/reports/2008/PF019.pdf > Accessed 3/11/09.

DeStefano, D.A., A.P. Grybauskas, J.L. Sherald, B. Momen, Q. Huang, and J.J. Sullivan. 2007. Effect of the growth regulator paclobutrazol on growth of the bacterial pathogen Xylella fastidiosa. Arboriculture \& Urban Forestry 33:246-252.

Gould, A.B., G. Hamilton, M. Vodak, J. Grabosky, and J. Lashomb. 2004. Bacterial leaf scorch of oak in New Jersey: Incidence and economic impact. Phytopathology 94:S36.

Gould, A.B., and J.H. Lashomb. 2005. Bacterial leaf scorch of shade trees. APSnet. <www.apsnet.ort/online/feature/bis/>

Garbelotto, M., D.J. Schmidt, and T.Y. Harnik. 2007. Phosphite injections and bark application of phosphite + Pentrabark control sudden oak death in coast live oak. Arboriculture \& Urban Forestry 33: 309-317.

Garbelotto, M., and D.J. Schmidt. 2009. Phosphonate controls sudden oak death pathogen for up to 2 years. California Agriculture 63: 10-17.

Hartman, J.R., C.A. Kaiser, U.E. Jarlfors, B.C. Eshenaur, P.A. Bachi, and W.C. Dunwell. 1991. Occurrence of oak bacterial leaf scorch caused by Xylella fastidiosa in Kentucky. Plant Disease 75:862.

Hartman, J.R., Eshenaur, B.C., and U.E Jarlfors. 1992. Shingle oak, a new host for bacterial leaf scorch caused by Xylella fastidiosa. Phytopathology 82:498 (abstract).

Hartman, J.R., B.C. Eshenaur, and U.E. Jarlfors. 1995. Bacterial Leaf Scorch Caused By Xylella fastidiosa: A Kentucky Survey; A Unique Pathogen; and Bur Oak, A New Host. Journal of Arboriculture 21: 77-82.

Hartman, J.R., U.E. Jarlfors, W.M. Fountain, and R. Thomas. 1996. First report of Bacterial Leaf Scorch Caused by Xylella fastidiosa on Sugar Maple and Sweetgum. Plant Disease 80:1302.

Hopkins, D.L. 1989. Xylella fastidiosa: Xylem-limited bacterial pathogen of plants. Annual Review of Phytopathology 27:271-290.

Hopkins, D.L. 2005. Biological control of Pierce's disease in the vineyard with a benign strain of Xylella fastidiosa. Phytopathology 95:S44. 
Kostka, J.J., T.A. Tattar, and J.L. Sherald. 1985. Suppression of bacterial leaf scorch symptoms in American elm through oxytetracycline microinjection. Journal of Arboriculture 11:54-58.

Pooler, M.R., I.S. Myung, J. Bentz, J. Sherald, and J.S. Hartung. 1997. Detection of Xylella fastidiosa in potential insect vectors by immunomagnetic separation and nested polymerase chain reaction. Letters in Applied Microbiology 25:123-126.

Schaad, N.W., E. Postnikova, G. Lacy, M.B. Fatmi, and C.-J. Chang. 2004. Xylella fastidiosa subspecies: X. fastidiosa subsp. piercei subsp. nov., $X$. fastidiosa subsp. multiplex subsp. nov., and X. fastidiosa subsp. pauca subsp. nov. Systematic and Applied Microbiology 27:290-300.

Sherald, J.L. 2007. Bacterial leaf scorch of landscape trees: What we know and what we do not know. Arboriculture \& Urban Forestry 33:376-385.

\section{John Hartman (corresponding author) \\ University of Kentucky \\ Plant Pathology \\ 201 Plant Science Building \\ 1405 Veterans Drive \\ Lexington, $K Y$ 40546, U.S.}

\section{Ed Dixon \\ University of Kentucky \\ Plant Pathology \\ 201 Plant Science Building \\ 1405 Veterans Drive \\ Lexington, $K Y$ 40546, U.S.}

Shawn Bernick

Rainbow Treecare Scientific Advancements

$11571 \mathrm{~K}-\mathrm{Tel} \mathrm{Dr}$

Minnetonka, MN, 55343, U.S.
Résumé. La brûlure bactérienne des feuilles est une maladie des arbres, spécialement chez les chênes dans les jardins du Kentucky. De 2003 à 2007, plusieurs méthodes de traitements thérapeutiques potentiels on été tentés sur des chênes des marais (Quercus palustris) situés dans un parcours de golf, le long de rues et dans des fermes équestres. Les traitements utilisés ont été des trempages de sol autour du pied de l'arbre avec du paclobutrazol, des applications de composés antimicrobiens assistés d'adjuvant (PentraBark) à la base du tronc, ainsi des injections printanières d'oxytétracycline au niveau du pied de l'arbre. Les trempage avec le paclobutrazol ont produit les effets anticipés de régulateurs de croissance mais n'ont pas permis de diminuer de manière probante les dommages par la brûlure bactérienne sur les arbres situés dans le golf et le long des rues. Les antibiotiques appliqués directement dans les troncs des arbres infectés au moyen d'un adjuvant n'ont eu aucun effet sur les degrés de dommages par la brûlure bactérienne. Comparativement aux arbres non traités, les injections printanières au pied de l'arbre d'oxytétracycline ont permis de réduire les degrés de dommages et ont permis de retarder de deux semaines le début de l'apparition des symptômes de dommages de fin d'été. Les injections faites trois semaines après la pleine expansion des premières feuilles ont donné de meilleurs résultats que les injections faites plus tôt ou plus tard au printemps. Les traitements thérapeutiques ne permettent pas de guérir totalement les arbres infectés par la brûlure bactérienne des feuilles, mais ils peuvent permettre de prolonger la vie de l'arbre.

Zusammenfassung. Bakterielle Blattwelke ist eine sehr ernste Krankheit für Bäume, besonders für Eichen in der Landschaft von Kentucky. Von 2003 bis 2007 wurden einige möglicherweise therapeutisch wirkende Krankheitsbehandlungen an bereits befallenen Sumpfeichen (Quercus palustris) auf Golfplätzen, an Straßen und auf Pferdefarmen ausprobiert. Diese Behandlugen bestanden aus Aufgüssen von $\mathrm{Pa}-$ clobutrazol, Stammimpfungen mit Anti-Mikrobiellen Komponenten und einem Hilfsmittel, sowie Wurzelinjektionen mit Oxytetracycline im Frühling. Paclobutrazol-Tränkungen verursachten die erwartete Wachstumsregulierung, aber sie reduzierten nicht nachhaltig die Infektion auf den Golfplätzen und bei den Straßenbäumen. Die direkt in den Stamm infizierter Bäume applizierten Antibiotika mit einem Hilfsmittel hatten keinen Einfluss auf die bakterielle Blattwelke. Verglichen mit unbehandelten Bäumen konnten die Wurzelinjektionen mit Oxytetracycline im Frühling die Welkesymptome reduzieren und verzögerten das Auftreten von Symptomen im Spätsommer um zwei Wochen. Injektionen, die drei Wochen nach dem Blattaustrieb ausgeführt wurden, lieferten bessere Ergebnisse als früher oder spatter ausgeführte Injektionen im Frühjahr Die therapeutischen Maßnahmen liefern keine Kur für bereits erkrankte Bäume, aber sie können möglicherweise .das Leben verlängern.

Resumen. La quemadura bacterial foliar es un seria enfermedad de los árboles, especialmente en encinos, en paisajes de Kentucky. De 2003 a 2007 , se ensayaron varios tratamientos terapéuticos en encinos enfermos (Quercus palustris) creciendo en un campo de golf, en la calle, y en ambientes de granjas equinas. Los tratamientos incluyeron zanjas alrededor de la corona de las raíces con paclobutrazol, adyuvante con aplicaciones al tronco de compuestos anti-microbiales, e inyecciones de oxytetracycline. Las zanjas con Paclobutrazol causaron efectos de regulación del crecimiento pero no redujeron significativamente la enfermedad en los campos de golf y árboles en calles. Los antibióticos aplicados directamente a los troncos de árboles infestados con un adyuvante no afectaron los niveles de síntomas de la quemadura en el otoño. Las inyecciones hechas en las tres semanas después de la expansión del crecimiento de las primeras hojas dieron mejores resultados que las inyecciones hechas temprano o tarde en la primavera. Los tratamientos terapéuticos no proporcionan un cura para los árboles infestados con la enfermedad bacterial, pero pueden prolongar la vida del árbol. 